\title{
Land use change detection in Solan Forest Division, Himachal Pradesh, India
}

\author{
Shipra Shah ${ }^{1 *}$ and DP Sharma ${ }^{2}$
}

\begin{abstract}
Background: Monitoring the changing pattern of vegetation across diverse landscapes through remote sensing is instrumental in understanding the interactions of human activities and the ecological environment. Land use pattern in the state of Himachal Pradesh in the Indian Western Himalayas has been undergoing rapid modifications due to changing cropping patterns, rising anthropogenic pressure on forests and government policies. We studied land use change in Solan Forest Division of Himachal Pradesh to assess species wise area changes in the forests of the region.
\end{abstract}

Methods: The supervised classification (Maximum likelihood) on two dates of IRS (LISS III) satellite data was performed to assess land use change over the period 1998-2010.

Results: Seven land use categories were identified namely, chir pine (Pinus roxburghii) forest, broadleaved forest, bamboo (Dendrocalamus strictus) forest, ban oak (Quercus leucotrichophora) forest, khair (Acacia catechu) forest, culturable blank and cultivation. The area under chir pine, cultivation and khair forests increased by 191 ha (4.55\%), 129 ha (13.81\%) and 77 ha (23.40\%), whereas the area under ban oak, broadleaved, culturable blank and bamboo decreased by 181 ha (16.58 \%), 152 ha (6.30 \%), 71 ha (2.72 \%) and 7 ha (0.47 \%), respectively.

Conclusions: The study revealed a decrease in the area under forest and culturable blank categories and a simultaneous increase in the area under cultivation primarily due to the large scale introduction of horticultural cash crops in the state. The composition of forests also exhibited some major changes, with an increase in the area of commercially important monoculture plantation species such as pine and khair, and a decline in the area of oak, broadleaved and bamboo which are facing a high anthropogenic pressure in meeting the livelihood demands of forest dependent communities. In time deforestation, forest degradation and ecological imbalances due to the changing forest species composition may inflict irreversible damages upon unstable and fragile mountain zones such as the Indian Himalayas. The associated common property externalities involved at local, regional and global scales, necessitate the monitoring of land use dynamics across forested landscapes in developing future strategies and policies concerning agricultural diversification, natural forest conservation and monoculture tree plantations.

Keywords: Land use; Solan Forest Division; Supervised Classification; Maximum likelihood

\footnotetext{
* Correspondence: drshiprashah1984@gmail.com

'Department of Forestry, College of Agriculture, Fisheries and Forestry, Fiji

National University, NasinuP.O. Box 7222, Fiji Islands

Full list of author information is available at the end of the article
} 


\section{Background}

Very few landscapes remain on Earth that have not been significantly altered by the human race in one way or another (Yang 2001). Land use land cover (LULC) change is the primary modifier of landscapes, affecting a wide range of socioeconomic, biological, climatic, and hydrological systems (Sohl and Sohl 2012). Understanding the spatial extent and distribution of LULC change is vital to the study of environmental changes at various levels (Ojima et al. 1994). LULC change is one of the key drivers of local and regional climate change (Chase et al. 1999), biodiversity decline (Sala et al. 2000), soil degradation (Tolba and El-Kholy 1992) and the loss of ecosystem services, thereby affecting the ability of ecosystems to support human needs (Vitousek et al. 1997). Population growth, rapid economic development and poverty have been identified as the underlying causes of land use change resulting in deforestation and land degradation (Giri et al. 2003; Bolland et al. 2007).

During the 1960s the concept of vegetation mapping gained momentum, resulting in an increase in studies of LULC change worldwide (Yang 2001). It is universally acknowledged that declining forest cover triggers ecological problems like changes in global climate, habitat degradation and unprecedented species extinction (Goldsmith 1998). Atmospheric carbon dioxide concentration is now higher than at any time in the past 10 million years (Kennedy and Hanson 2006). It is estimated that forests (including associated soils, peat deposits and lake sediments) hold $62-78 \%$ of the world's terrestrial biospheric carbon (IPCC 2001). Forest clearing is one of the major drivers of global warming and climate change. The world's forests particularly those in the tropics are shrinking at a dramatic rate (Apan 1999). Anthropogenic activities involving forests, such as land use change can alter the amount and temporal distribution of C storage (Adams et al. 1993; Haynes et al. 1994). According to Achard et al. (2014), the gross loss of tropical forests was 8.0 million ha $\mathrm{yr}^{-1}$ in the 1990s and 7.6 million ha $\mathrm{yr}^{-1}$ in the 2000s, which resulted in

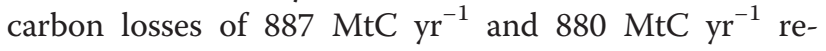
spectively during the same period. It is imperative that regular periodic assessments of forest cover change in tropical regions are carried out to recognize previous patterns, assist proper planning and predict future trends. The use of remote sensing data has been instrumental in monitoring the changing pattern of vegetation across diverse landscapes. The capacity for large geographical coverage, high temporal frequency and wide selection of spatial and spectral resolution options, further enhances the use of remotely sensed imagery for LULC change detection.

LULC change is primarily a local event, since the characteristics of such change can vary dramatically from one region to another. In order to capture the uniqueness of each region it is necessary that LULC studies are conducted at local to regional scales to better understand the cumulative impacts at multiple scales (Sohl et al. 2004). Over the years land use and cropping patterns in the western Himalayan state of Himachal Pradesh have been changing. The expansion of cultivation at the expense of forests has been relatively more profound in Himachal Pradesh than other parts of India (Melkania and Melkania 1987). The introduction of horticultural cash crops and the commercialization of agriculture have placed greater demands on the forests (Gouri et al. 2004) of the state which have not only been undergoing a change in area but also a change in composition primarily due to human interference (Deshingkar et al. 1997). To arrest forest degradation the state government has been involved in raising monoculture tree plantations of species such as pine which offer relatively less ecological and economic services to forest dependent communities as compared to mixed broadleaved forests (Baland et al. 2008). Another grievous cause of concern is the replacement of oak by pine in the Indian Western Himalayas. Thus, the forested landscapes in the state are undergoing major transformations. Some LULC change studies have been conducted in Himachal Pradesh (Sharma et al. 2014, Singh et al. 2014, Chand and Chatranta 2014, Pareta 2014, Pareta and Pareta 2014, Ramachandra et al. 2012) but none have specifically focused on the change in the forests of the region to highlight specific trends in species area and composition. Therefore, the present study is an attempt to study land use change in Solan Forest Division, to highlight species wise area changes which can play an indispensible role in developing future strategies and policies concerning natural forest conservation and monoculture tree plantations.

\section{Methods}

\section{Study area}

The population of Himachal Pradesh as per the Census of India, 2011 is 6.86 million, with a decadal growth rate of $12.81 \%$. Around $90 \%$ of the total population lives in rural areas and consequently people are highly dependent upon forests for their livelihoods (Gouri et al. 2004). Local communities depend on forests for fuelwood, fodder, grazing, non-timber forest products and construction timber through Timber Distribution (TD) rights. There has been an ever increasing pressure on the forest resources due to the rising population on one hand as well as limited and fragmented agricultural land on the other.

The state has a predominantly agro-horti-pastoral economy. Apart from forests around $87 \%$ of the population also depends on agriculture (Gouri et al. 2004). 
While in the lower valleys agriculture and animal husbandry form the backbone of the economy, at higher altitudes, agro-pastoral systems predominate. Due to a high population density per unit area of agricultural land, and small size of landholdings- $64 \%$ are less than 1 ha (Gouri et al. 2004), agriculture which was primarily for subsistence and considered an uneconomic vocation was diversified into horticulture which has relatively higher yields per unit area in terms of money than other agricultural crops (Ahluwalia 1998). Temperate fruits like apple, pear, stone fruits, nuts; subtropical fruits like mango, litchi, guava, citrus fruits; and new fruits crops like kiwi, strawberry, olive and hazelnuts have been introduced in recent years and have since become a major source of the export earnings of the state. Himachal Pradesh is now known as the fruit bowl of India and today the agriculture sector provides direct employment to around $71 \%$ of the total working population (Kumar and Prashar 2012).

The present study was carried out in Solan Forest Division of Himachal Pradesh, which is located between $30^{\circ} 45^{\prime} 00^{\prime \prime}$ to $31^{\circ} 10^{\prime} 00^{\prime \prime} \mathrm{N}$ latitude and $76^{\circ}$ $55^{\prime} 00^{\prime \prime}$ to $77^{\circ} 15^{\prime} 00^{\prime}$ E longitude. The area falls under subtropical region where climate varies from extreme hot in the lower elevations to extreme cold in higher elevations. Temperature in lower areas ranges between 15 and $36{ }^{\circ} \mathrm{C}$ and in higher areas it varies from 0 to $24{ }^{\circ} \mathrm{C}$. Precipitation is in the form of rains mainly during rainy season and the area receives on an average $1000 \mathrm{~mm}$ annual rainfall.

The forests of the division are pure and mixed stands of chir pine and mostly conform to Champion and Seth (1968) $9 \mathrm{C}_{1} \mathrm{a}$ - lower Shiwalik chir pine forests, lying between an elevation of 900-2100 $\mathrm{m}$ a.s.l. The area above $1800 \mathrm{~m}$ a.s.l is inhabited by oak forests. Low lying areas show widespread population of bamboos and are also a transitional zone for Acacia catechu.

\section{Methodology}

Cloud free IRS 1D (LISS-III) satellite data were acquired for winter months, 26 December, 1998 and 17 January, 2010 (Fig. 1), from the National Remote Sensing Agency (NRSA), Government of India, Hyderabad. Obtaining images at near anniversary dates is considered important for change detection studies (Jensen, 2007). The stock map and inventory reports available with Solan Forest Division were used to derive information on forest ranges, forest compartments and land uses. These were further confirmed by ground truthing. The stock map was digitized for forest compartments and land use types distributed in the different ranges of the division. Forest compartment coverage was then imported into IDRISI Taiga (Clark lab, Clark University, Worcester MA, USA) for further processing. Toposheets (1: 25000 scale) pertaining to Solan Forest Division were procured from FSI (Forest Survey of India) and used to digitise contours at $20 \mathrm{~m}$ interval using CARTALINX 1.2 data builder. The Digital Elevation Model (DEM) for the division was prepared by processing these cartographic features using IDRISI Taiga.

Preprocessing of the images was done through atmospheric and geometric rectifications. The LISS III images were corrected for atmospheric path radiance using dark object subtraction method (Chavez 1988), wherein the pixel (associated with the dark object) having minimum brightness value in the near infrared band was detected and the corresponding pixel values in all other bands were subtracted from the specific raw bands. This resulted in an image corrected for atmospheric scattering. The images were re-sampled for all bands using the nearest neighbor method, so that the original brightness values of pixels were kept unchanged. The resultant root mean squared error was found to be less than 1 pixel for both the images, 0.001465 pixels for the 1998 image and 0.000201 pixels for the 2010 image. Image enhancement
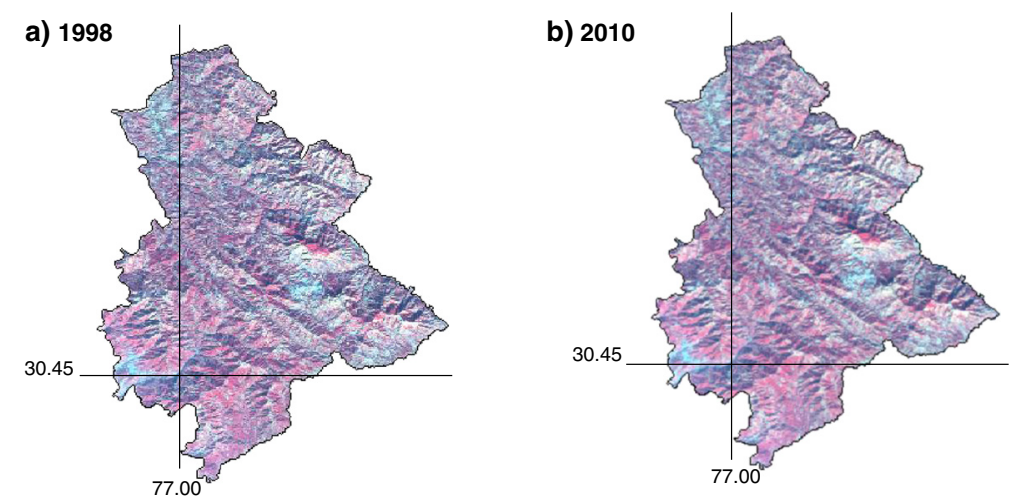

Fig. 1 IRS 1D (LISS-III) satellite images a) 1998 and b) 2010 
techniques such as histogram stretching, median filtering and compositing were also applied to aid visual interpretation. While histogram stretching is a linear stretch technique used for adjusting image intensities to enhance contrast; median filtering aids in random noise removal by creating an output image in which each pixel's value is based on its value and those of its immediate neighbors in an input image. Colour composite images allow us to view the reflectance information from three separate bands in a single image, and were created by using the bands which had the greatest amount of information, least redundancy and low relativity.

The training sites were determined and a supervised classification was performed on both images using Maximum Likelihood algorithm. The supervised classification technique is preferred, because the data of the study area is available and the authors have a prior knowledge of the area. The Maximum Likelihood decision rule is one of the most widely used supervised classification algorithms (Wu and Shao 2002; McIver and Friedl 2002). Land use classification was first done for the whole area of Solan Forest Division, 57,158 ha (recorded forest area + non-forest area) and then from these classified images, the forest compartments 13,067 ha (recorded forest area) within the division were extracted, to assess the land use change in the forests of the division. As a result the land use maps depicting seven different land uses were derived. The flowchart elucidating the development of land use maps is given in Fig. 2.

A complete accuracy assessment was performed on classified images of the two dates generated during this study. A sample of ground truth points were distributed randomly on the classified image. Total 450 points were overlaid over the classified image to assign to each point an identifier of the land cover type. The ground truth data (reference data) used were collected from field surveys and existing stock map that had been field checked. An error matrix was established to evaluate the accuracy of the classification. This is a very effective way to represent the accuracy of the classification results, as the accuracy of each category is clearly described (Fan et al. 2007). Overall accuracy, user and producer accuracies and the Kappa statistics, were derived from the error matrices. The overall accuracy was defined as the total number of correctly classified pixels divided by the total number of reference pixels (total number of sample points) (Rogan et al. 2002). The user accuracy was defined as the proportion of the correctly classified pixels in a class to the total pixels that were classified in that class. It indicates the probability that a classified pixel actually represents that category in reality. The producer accuracy was calculated by dividing the total number of correctly classified pixels in a class by the total number of reference measurements of that class and it is the probability that a class identified from the reference data is correctly classified on the map. The KHAT statistics (an estimate of Kappa), which provides a measure of how many more pixels were correctly classified than expected by chance (Congalton and Green 1999), was computed through the following formula:

$$
k=\frac{0-E}{1-E}
$$

where: $\mathrm{k}$ represents the Kappa Index of Agreement; O is the observed accuracy or proportion of matching values (the matrix diagonal) i.e. the sum of the diagonal elements divided by the overall total; and $\mathrm{E}$ is the expected proportion of matches in this diagonal i.e. the sum for each diagonal cell of the row total times the column total divided by the overall total squared.

\section{Results}

Cartographic features obtained from the stockmap of Solan Forest Division revealed that it covers five forest ranges namely Dharampur, Parwanoo, Solan, Kandaghat and Subathu (Fig. 3). The area under these ranges was in the order, Subathu (14198 ha) > Dharampur (11564 ha) > Solan (11027 ha) > Parwanoo (10688 ha) > Kandaghat (9681 ha). Within these five forest ranges are distributed around 256 forest compartments (Fig. 4). Dharampur is the largest range having the maximum number of forest compartments (94), followed by Parwanoo (75), Solan (37), Kandaghat (35) and Subathu range (15). In these forest compartments, seven types of land uses were identified. These are: 1 ) chir pine (Pinus roxburghii) forests, 2) ban oak (Quercus leucotricophora) forests 3) khair (Acacia catechu) forests 4) bamboo (Dendrocalamus strictus) forests 5) broad leaved forests 6) cultivation and 7) culturable blank.

\section{Accuracy assessment}

The user accuracy ranged between 74-93\% in 1998 and, $85-92 \%$ in 2010 (Table 1). Producer accuracy ranged between $79-96 \%$ in 1998 and, 86 and $92 \%$ in 2010 (Table 1). Classification accuracy as a result of maximum likelihood classification resulted in an overall accuracy of 87 and $89 \%$ and KHAT accuracy of 85 and $87 \%$ in 1998 and 2010, respectively (Table 2).

\section{Changes in Land use (1998-2010)}

Land use classification was first done for the whole area of Solan Forest Division which is spread over 57,158 ha and includes both recorded forest area and non-forest area (Fig. 5) and then from these classified images, the forest compartments spread over 13,067 ha within the division (recorded forest area) were extracted, to assess the land use change in the forests of the division (Fig. 6). 


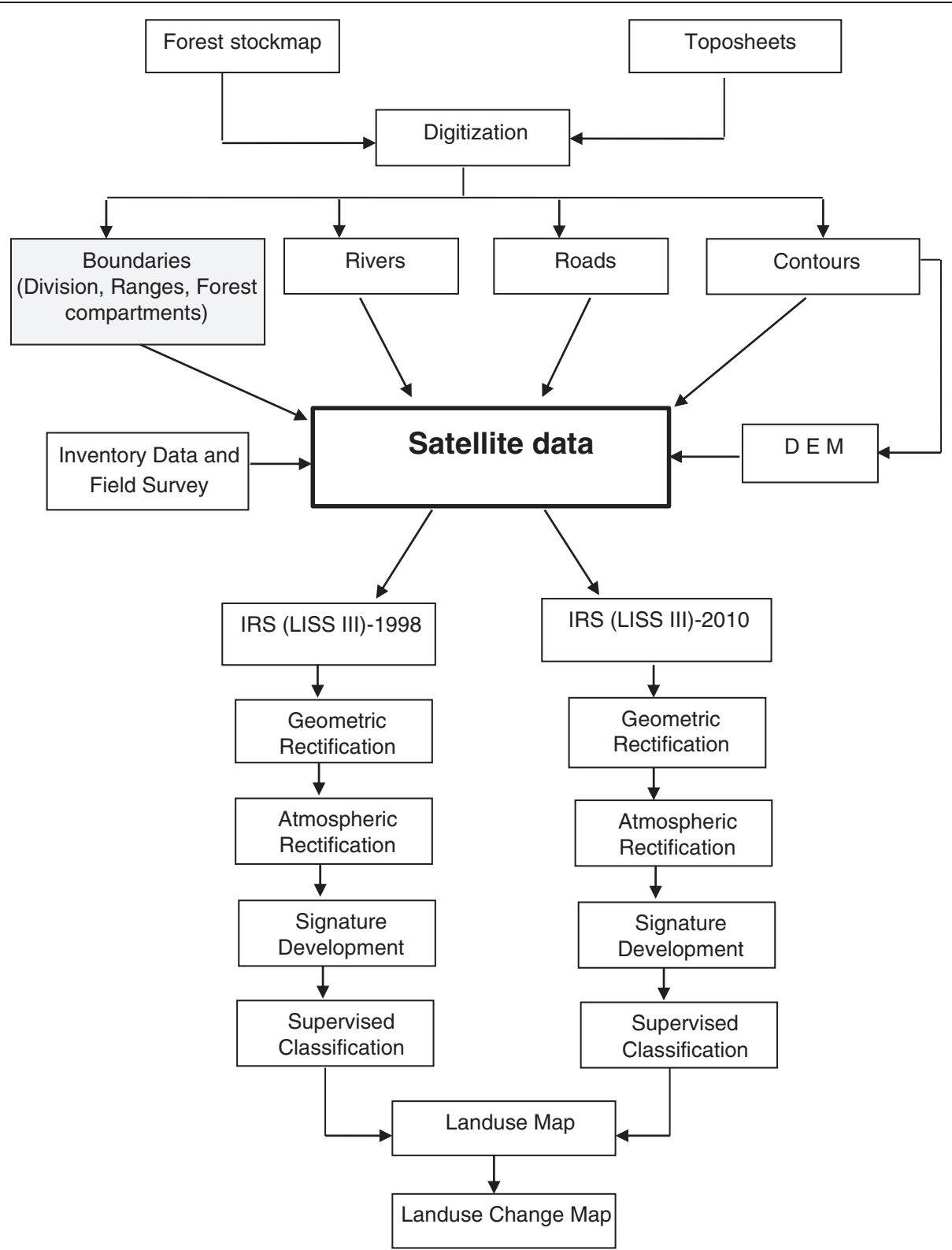

Fig. 2 Flow chart of the procedure followed to develop land use maps for Solan Forest Division

In 1998 the distribution of the various land use categories i.e. chirpine, culturable blank, broadleaved, bamboo, ban oak, cultivation and khair was over 4200, 2608, 2413, 1491, 1092, 934 and 329 ha area which accounted for $32.14,19.96,18.47,11.41,8.36,7.15$, and $2.52 \%$ of the total area, respectively (Table 3). In 2010 chirpine, culturable blank, broadleaved, bamboo, cultivation, ban oak and khair land use categories covered 4391, 2537, 2261, 1498, 1063, 911 and 406 ha which accounted for $33.60,19.42,17.30,11.46,8.13,6.97$ and $3.11 \%$ of the total area, respectively. Chirpine, cultivation and khair increased in area by 191 ha (4.55\%), 129 ha (13.81\%) and 77 ha $(23.40 \%)$ respectively from 1998 to 2010. Ban oak, broadleaved, culturable blank and bamboo decreased in area by 181 ha (16.58\%), 152 ha (6.30\%), 71 ha $(2.72 \%)$ and 7 ha $(0.47 \%)$ respectively (Table 3$)$. The area under forest and culturable blank decreased by 72 and 71 ha respectively while that under cultivation increased by 129 ha.

\section{Discussion}

The computed accuracies of the classification process were reasonable which can be explained by the fact that the total number of correctly classified pixels was high. User accuracy as a result of maximum likelihood classification ranged between 74-93 \% in 1998 and 85-92 \% in 


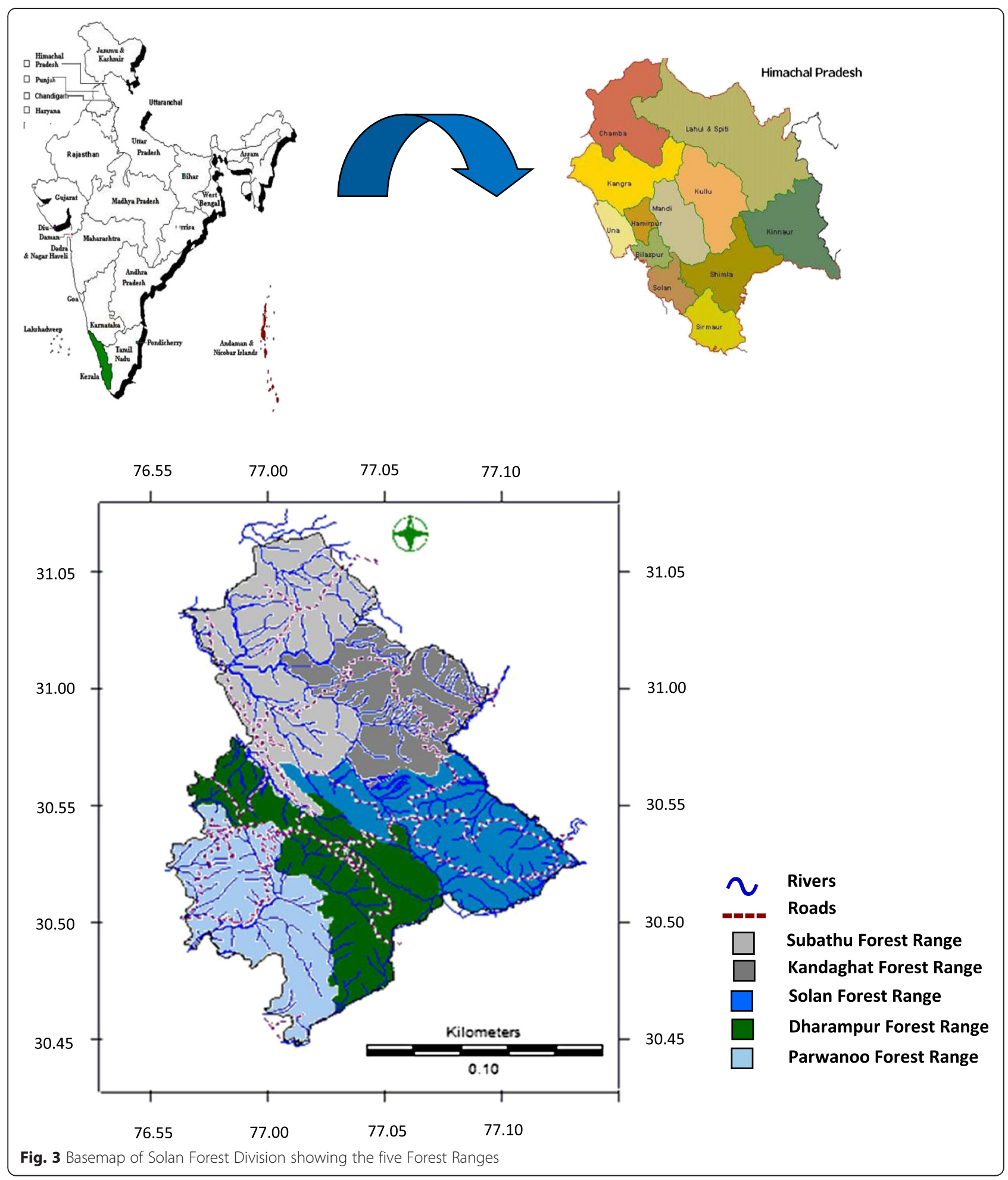

2010; while producer accuracy ranged between 79-96 \% in 1998 and $86-92 \%$ in 2010. Pareta (2014) in a study on land use and land cover change in Baddi district of Solan, has reported user accuracy for various lands cover classes between 93-100 \% while producer accuracy between 83-100 \%. Sharma and Leon (2005)) while working on land cover classification of Solan district using IRS (LISS III) data of different seasons reported a user accuracy ranging between 64-89\%, 32 and $68 \%$, 23-62 \%; and producer accuracy between 46-100 \%, 33 


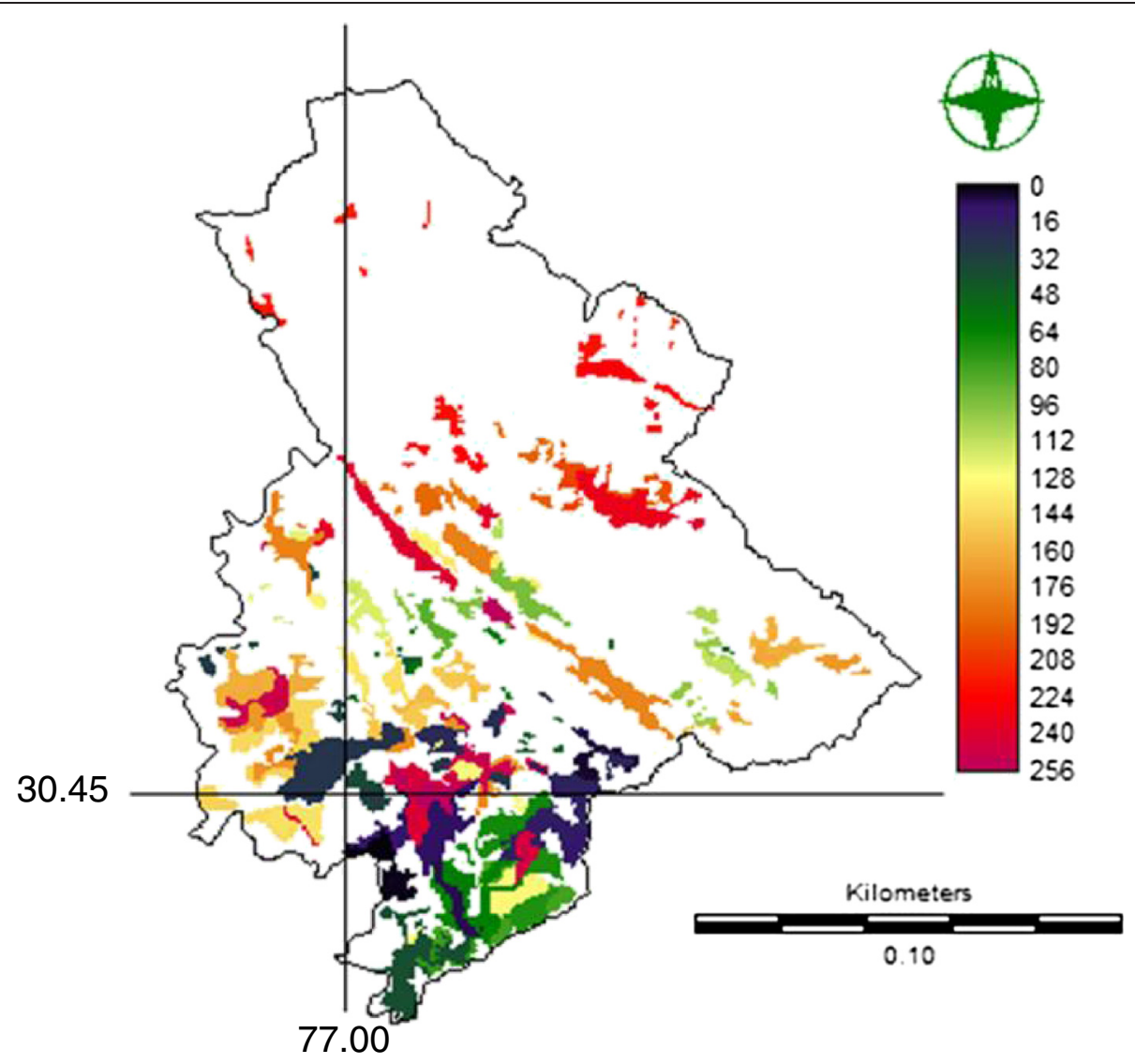

Fig. 4 Data Layer of Forest Compartments in Solan Forest Division

and $74 \%, 28-80 \%$, in summer, winter and spring datasets respectively, as a result of maximum likelihood classification. Overall accuracy in the present study for the different land use categories was 87-89\% in 1998 and 2010, respectively. Overall accuracies of $76 \%$ in summer dataset as compared to $49 \%$ and $46 \%$ in winter and spring datasets respectively, have been reported by Sharma and Leon (2005). Ramachandra et al. (2012) while studying landscape dynamics of Mandhala watershed in Solan district of Himachal Pradesh using IRS LISS III and Landsat data reported overall accuracies ranging between 78.52-86.52\%. KHAT accuracies of 85 $\%$ and $87 \%$ in 1998 and 2010 land use classifications respectively were computed in the present study. Comparatively lower accuracy as per 1998 classification was due to relatively higher mixing of spectral signatures between different land use categories in 1998 than in 2010. Sharma and Leon (2005) have reported KHAT accuracies of $71 \%, 40 \%$ and $38 \%$ for summer, winter and spring datasets respectively.

The land use classification showed a decrease in the area under both forest and culturable blank, and an increase in the area under cultivation. Similar results have been reported by Ramachandra et al. (2012), in Mandhala watershed, district Solan, where the area under forest decreased by 537.04 ha and the area under cultivation increased by 33.93 ha over the period 1972-2007. Pareta (2014) reported a decrease in the forest cover by $54.95 \mathrm{~km}^{2}$ and an increase in cropland by $1.66 \mathrm{~km}^{2}$ in Baddi town of district Solan over 1990-2013. Pareta and Pareta (2014) reported a decline in agricultural land and dense forest by $41.42 \mathrm{~km}^{2}$ and $112 \mathrm{~km}^{2}$ respectively over 2001-2013 in Chamba district of Himachal Pradesh.

Land use pattern in Himachal Pradesh has undergone tremendous transformation due to changes in agriculture cropping pattern, urbanization and industrialization. Crop diversification gained momentum in the nineties and now covers several new areas in low and mid hill districts of the state (Sharma, 2011). With the integration of horticultural cash crops, changing land use and cropping patterns have evolved (Sharma et al. 2007; Singh 1999). The area under horticulture in the state registered an enormous increase from 86230 ha in 1980-1981 to 186900 ha in 2005-2006. In Solan the per cent share of area under non-foodgrain crops increased from $8.25 \%$ in $1982-1983$ to over $12.96 \%$ in $2004-$ 2005 (Sharma, 2011). While only about $11 \%$ of the total geographical area of the state is available for cultivation 
Table 1 Error matrices as a result of land use classification for 1998 and 2010

\begin{tabular}{|c|c|c|c|c|c|c|c|c|c|}
\hline \multicolumn{10}{|l|}{ Reference data 1998} \\
\hline Classified data & Ban oak & Chirpine & Culturable Blank & Broadleaved & Bamboo & Cultivation & Khair & Total & User accuracy \\
\hline Ban oak & 46 & 3 & 1 & 0 & 0 & 1 & 0 & 51 & 90 \\
\hline Chirpine & 1 & 64 & 2 & 4 & 0 & 0 & 0 & 71 & 90 \\
\hline Culturable Blank & 1 & 6 & 65 & 0 & 0 & 3 & 0 & 75 & 87 \\
\hline Broadleaved & 1 & 0 & 3 & 59 & 2 & 0 & 3 & 68 & 87 \\
\hline Bamboo & 1 & 0 & 0 & 9 & 48 & 5 & 2 & 65 & 74 \\
\hline Cultivation & 0 & 1 & 4 & 0 & 0 & 66 & 0 & 71 & 93 \\
\hline Khair & 0 & 1 & 0 & 3 & 0 & 0 & 45 & 49 & 92 \\
\hline Total & 50 & 75 & 75 & 75 & 50 & 75 & 50 & 450 & \\
\hline Producer accuracy & 92 & 85 & 87 & 79 & 96 & 88 & 90 & & 87 \\
\hline \multicolumn{10}{|l|}{ Reference data 2010} \\
\hline Ban oak & 43 & 3 & 1 & 0 & 0 & 0 & 0 & 47 & 91 \\
\hline Chirpine & 4 & 67 & 1 & 3 & 0 & 1 & 0 & 76 & 88 \\
\hline Culturable Blank & 0 & 1 & 68 & 3 & 0 & 3 & 0 & 75 & 91 \\
\hline Broadleaved & 1 & 2 & 1 & 65 & 2 & 1 & 2 & 74 & 88 \\
\hline Bamboo & 0 & 1 & 0 & 3 & 46 & 1 & 3 & 54 & 85 \\
\hline Cultivation & 2 & 1 & 4 & 0 & 0 & 68 & 0 & 75 & 91 \\
\hline Khair & 0 & 0 & 0 & 1 & 2 & 1 & 45 & 49 & 92 \\
\hline Total & 50 & 75 & 75 & 75 & 50 & 75 & 50 & 450 & \\
\hline Producer accuracy & 86 & 89 & 91 & 87 & 92 & 91 & 90 & & 89 \\
\hline
\end{tabular}

(Sharma, 2011), over the years growing area under horticultural cash crops has put increasing pressure on forest resources through land clearing (Sharma et al. 2010). In a study on forest based livelihoods in Himachal Pradesh, Gouri et al. (2004) reported that in two of the villages where apple cultivation was adopted 35 years ago, encroachment in forest areas for fruit production has reduced the forest cover to just $5 \%$ in Kiari and $3 \%$ in Dhadi Rawat village. In Kullu district of Himachal, encroachment of apple orchards into un-demarcated protected forest and demarcated protected forest is a common practice (ODA 1993). The use of wood for fruit packing cases also resulted in extensive deforestation in the state (Singh 1992). Up to mid-1980s, 0.2 million $\mathrm{m}^{3}$ of wood was extracted to make 20 million boxes annually for packaging of fruits and vegetables (Stokes, 1983). Alternative packaging materials like corrugated cardboard are being experimented with to deal with the problem of forest exploitation; however fruit growers have issues with the quality of the boxes.

Table 2 Comparison of two classification accuracy measures for two dates

\begin{tabular}{lll}
\hline Classification & Overall accuracy (\%) & KHAT accuracy (\%) \\
\hline 1998 & 87 & 85 \\
2010 & 89 & 87 \\
\hline
\end{tabular}

Rising population pressure and inappropriate policies of the government have further threatened forest sustainability and are contributing to deforestation and forest degradation. Nautor is an ancient right under which landless people are permitted to break fresh agricultural land in common land areas by village elders (ODA 1993). In 1968 the Himachal Pradesh Nautor Land Rules came into force whereby the government started granting nautor land (redistributed land) upto one acre to landless and other eligible people for agriculture and horticulture (Chowdhry, 2008). The un-demarcated forest is the land that was designated for allocation under nautor rights. This practice of giving away un-demarcated forest land to landless cultivators under the provisions of the said rules has resulted in deforestation in the Himalayan state (Gupta 2007). Another policy in the history of forest management in Himachal is the Timber Distribution (TD) system under which landowners or right holders claim rights to timber, primarily to meet house construction or repair needs. This policy while meeting the basic needs of the local population has also been the single largest reason for timber harvest in the western Himalayan region (Vasan 1998) due to the rampant misuse of these rights. Although the system was directed towards villagers, TD rights extended in urban areas as well. While previously the right to timber was unlimited it was later restricted to one or two trees once every five years. However, 


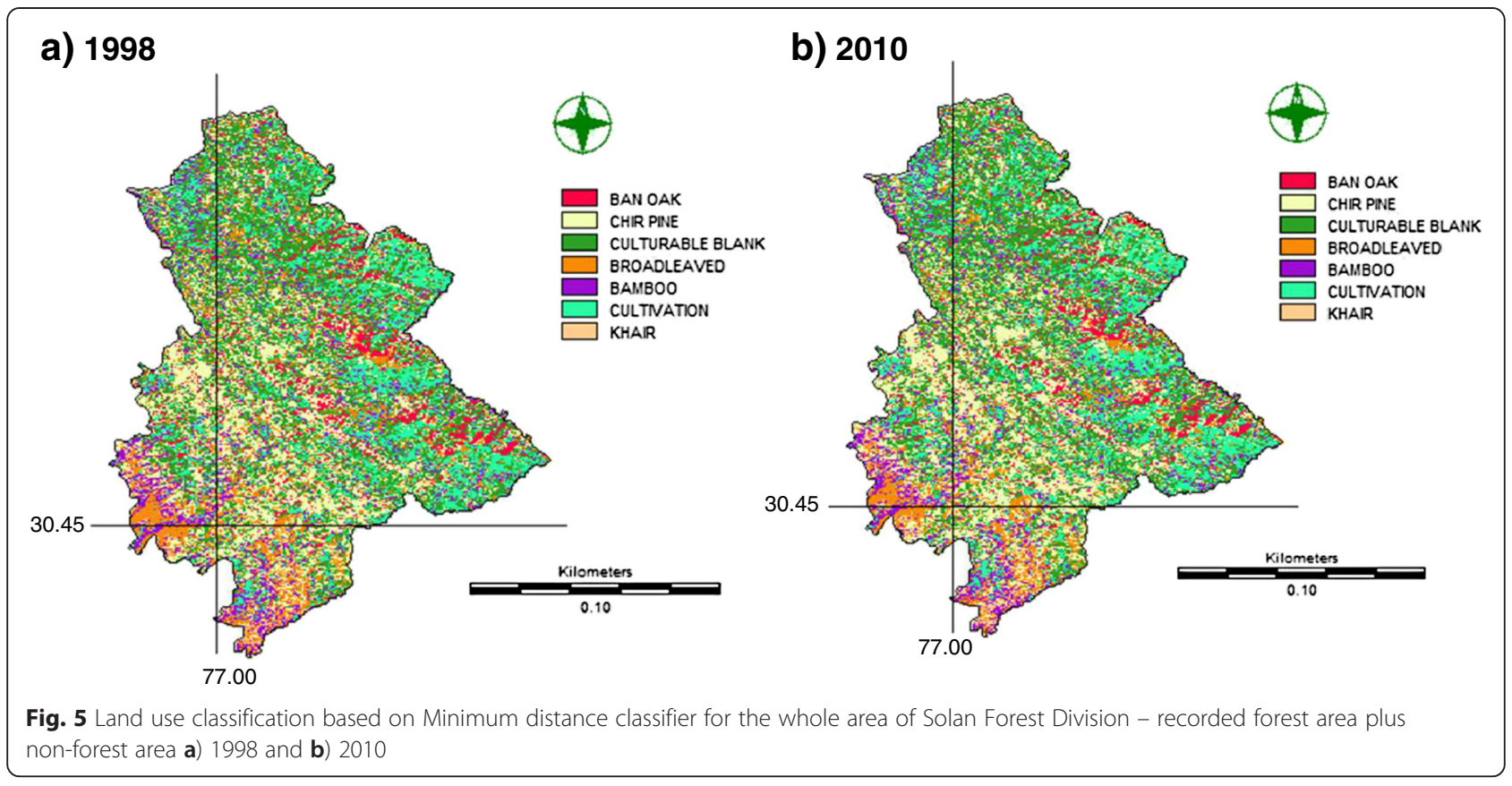

people were still paying the same nominal amount fixed in the last century which was about $20 \%$ of the market rate at the time of the initial forest settlements (Vasan 1998) i.e. a right holder could buy a tree for a subsidized rate as low as Rs 3 to 5. In 1992-1993 the subsidy provided by the forest department under TD was to the tune of Rs.795,600,000 (DFFC 1994). In time, the traditional timber distribution system was overrun by a timber mafia with approximately $150,000 \mathrm{~m}^{3}$ of timber (against a total growing stock of 96.8 million $\mathrm{m}^{3}$ ) carrying a market value of around Rs 750 million, extracted annually in the state under the TD rights, being siphoned off to timber industries (Gouri et al. 2004). This policy was later reviewed in light of a strong opposition, and the Himachal Pradesh Forest (Timber Distribution to the Right Holders) Rules, 2013 were notified on 26 December, 2013, which enhanced both the rates and periodicity for grant of TD rights. The government has also been funding massive monoculture plantation drives across the state to arrest forest degradation which however is able to generate relatively less ecological and economic services to forest dependent communities when

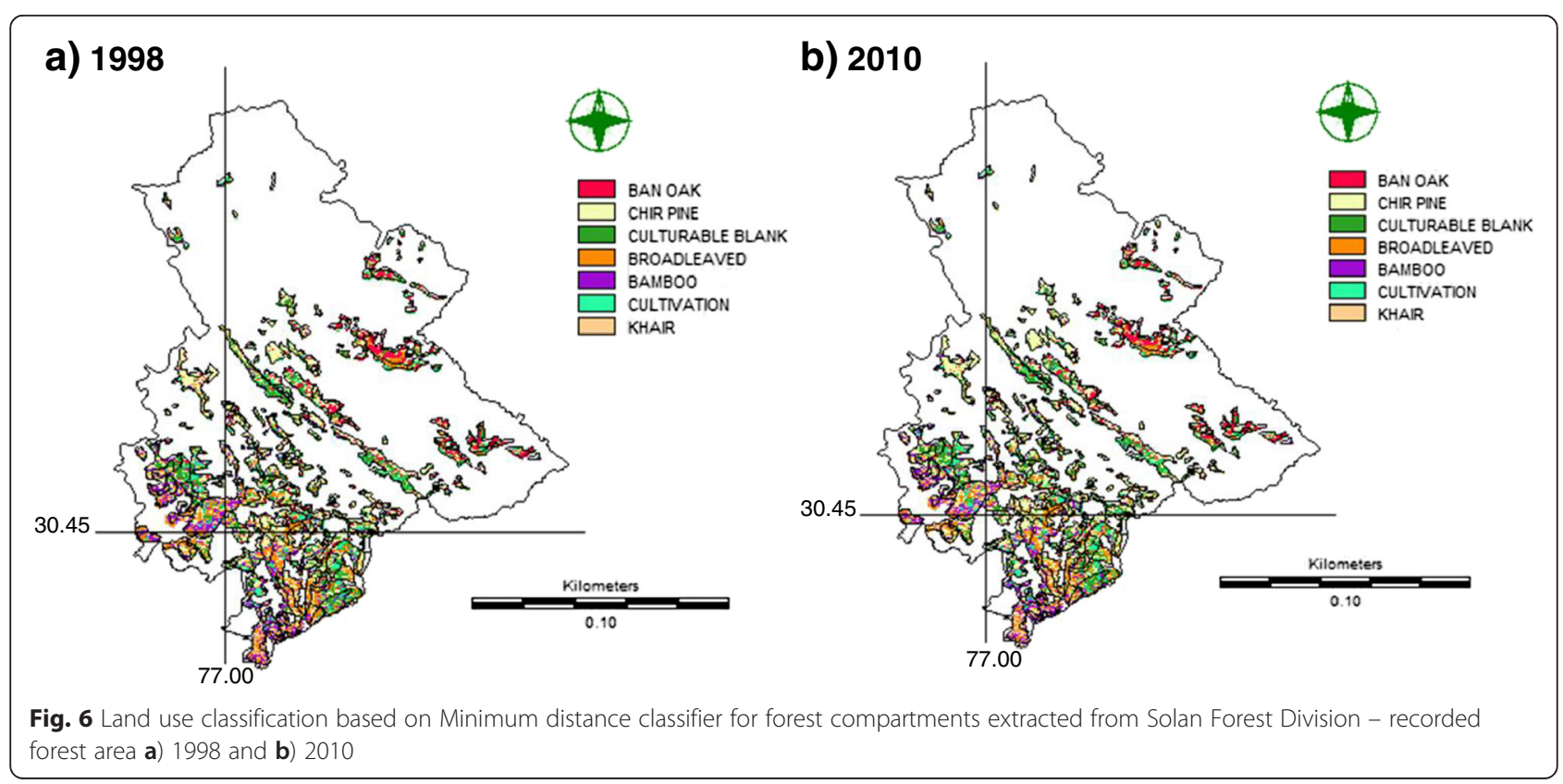


Table 3 Territorial (compartment wise) Land use change in Solan Forest Division

\begin{tabular}{llll}
\hline Category & \multicolumn{2}{l}{ Area under Land Use (ha) } & $\begin{array}{l}\text { \% Change } \\
\text { in Land } \\
\text { use Area }\end{array}$ \\
\cline { 2 - 3 } Cultivation & 1998 & 2010 & $129(+)$ \\
Culturable Blank & 934 & 1063 & $(13.81)$ \\
Forest Land use & $(7.15)$ & $(8.13)$ & $71(-)$ \\
Chir Pine & $(19.96)$ & 2537 & $(2.72)$ \\
Ban oak & 4200 & $(19.42)$ & \\
Broad Leaved & $(32.14)$ & $(33.6)$ & $191(+)$ \\
Khair & 1092 & 911 & $(4.55)$ \\
& $(8.36)$ & $(6.97)$ & $(181(-)$ \\
Bamboo & 2413 & 2261 & $152(-)$ \\
Total & $(18.47)$ & $(17.30)$ & $(6.30)$ \\
\hline & 329 & 406 & $77(+)$ \\
\hline
\end{tabular}

Figures in parenthesis are in percent

compared to mixed broadleaved forests and so the vicious cycle of forest degradation has remained unchecked. Such policies have a profound impact on forested landscapes and play a pivotal role in change of land use.

Within the forest land use category, chirpine and khair showed an increase in area, while ban oak, broadleaved and bamboo decreased in area over 1998-2010 period. Both chir pine and khair have been the primary plantation species of the state, where the focus has revolved more around commercially important species rather than ecologically valuable ones. An increase in the area of chir pine over the period 1998-2010 may be attributed to an increase in the area under plantations of chir pine. This species is being tapped for resin and is the largest species raised under plantations in Himachal Pradesh constituting about $30.60 \%$ of the total area under plantations and it registered an increase in area of 8265 ha over 1998-2001 (Planning Commission 2005). Also profuse regeneration under chir pine forests was observed during ground surveys of the study area. An increase in the area of khair may also be attributable to an increase in the area under plantations of khair which are a commercial source of kattha and cutch. While kattha is used in betel-vine preparations normally referred to as paan, cutch is a by-product of the kattha industry used for dyeing, colouring pulp in paper industry, water softening and in deep oil drilling operations. Khair is the second single largest species being raised under plantations in the state after chirpine constituting
$17.64 \%$ of the total area under plantations, and over 1998-2001 period, there has been reported an increase by over 7497 ha in the area under this species (Planning Commission 2005).

Conversely, a decrease in the area of ban oak may be attributed to heavy anthropogenic pressure on oak forests in hill states which results in indiscriminate lopping of the species. Ban oak is a multipurpose species having a good fodder and fuel quality; hence, it is under a high biotic stress in Himalayan forests (Saxena et al. 1978; Tiwari and Singh 1982; Bankoti et al. 1986; Joshi and Tiwari, 2011). Gouri et al. (2004), reported scarcity of fodder in Himachal Pradesh due to factors like forest fire, decrease in grasslands and mounting land utilisation pressure due to the adoption of horticulture. This has resulted in people keeping fewer cattle thereby affecting the availability of cow dung and natural manure. As a result the fuel requirements which were to some extent met through cow dung cakes, are now solely dependent on forests (Gouri et al. 2004) such as those of oak which are facing the problem of severe degradation. The total annual consumption of rural domestic fuel in the state is around 2.5 to 3.2 million tones, half of which is extracted from public forests (Singh and Sikka 1992). Decrease in the area of ban oak may also be due to poor regeneration observed in these forests compared to forests of chir pine in ground surveys of the study area. According to Bhandari et al. (1997), the regeneration potential of Pinus roxburghii is greater than that of Quercus species.

In the present study it is pertinent to observe that the increase in the area of pine namely 191 ha, is comparable with the decline in the area of oak namely 181 ha. This may be due to the replacement of oak by pine which has become an ever increasing phenomenon in the Western Himalayas (Singh et al. 1984). The exploitive management practices exerted by hill population in oak forests have encouraged pine (Saxena et al.1984). Forests in the Indian Himalayas are burnt periodically by the local communities to encourage the growth of grasses. This increases the preponderance of fire-resistant species such as chir pine. The aggressiveness of chir pine and its capacity to colonize disturbed sites have enabled it to spread at the expense of ban oak forests which are under immense biotic pressure (Singh and Singh 1984).

A decrease in the area of broadleaved forests which includes species such as Terminalia belerica, T. chebula, Dalbergia sissoo, Pyrus pashia, Albizzia chinensis, Juglans regia and Celtis australis, has also been observed in the present study, primarily due to the anthropogenic pressure of the forest fringe communities. According to Baland et al., 2008, broad-leaved forests tend to be more useful and consequently more degraded than coniferous forests. The former are of 
greater utility to adjacent villages due to the superior quality of firewood and fodder, and are also a source of several non-timber forest products. The decrease in the area under bamboo forests may be attributed to pressure on bamboo for its commercial purposes. In Himachal Pradesh, bamboo forests are considered economically very important and support local livelihoods. Several villagers generate income from them by making use of bamboo in basket making (Gouri et al. 2004).

\section{Conclusion}

Land use change reflects the role of human activities on natural resources and the environment. Analysis of the spatial and temporal pattern of land use and assessment of the key driving factors behind the associated changes is imperative for sustainable use of land and its resources. The present study characterized the land use change of Solan Forest Division in Himachal Pradesh where the area under forests and culturable blank has been decreasing while that under cultivation shows an increasing trend. The forests of the division also exhibit some major changes in terms of species composition and area, specifically, an increase in the area of commercially important monoculture plantation species such as pine and khair, and a simultaneous decrease in the area of ecologically important oak and broadleaved forests which are under a high biotic stress. Human driving forces emerge as the key factor responsible for land use change in the region. This study highlights how the commercialization of agriculture, anthropogenic pressure on forests and government policies have, the potential to significantly alter land use pattern across mountain ecosystems. There is an immediate need to periodically monitor LULC change across forested areas to assist decision making and future policies concerning agriculture and forestry, both of which are a way of life for the people in the hills of India and nevertheless play a pivotal role in landscape modification. The cumulative effects of deforestation, forest degradation and changes in the species composition of forests in the long run may have far reaching adverse impacts on people, livelihoods, sustainability and the forest ecosystem services flowing from the Indian Himalayan Region.

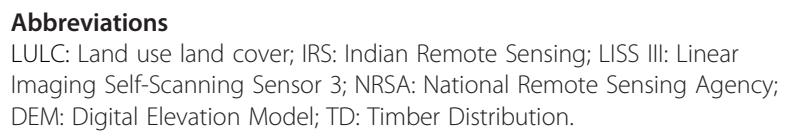

\section{Competing interests}

The author(s) declare that they have no competing interests.

\section{Authors' contributions}

SS carried out the image analysis, designed and drafted the manuscript. DP was involved in the acquisition of the satellite imageries, interpretation of the data and in revising the manuscript. Both authors read and approved the final manuscript,

\section{Authors' information}

1) SS participated in this research as a doctoral student. Currently she is working in the Department of Forestry, College of Agriculture, Fisheries and Forestry, Fiji National University, Nasinu, Fiji Islands.

2) DP is a professor of Silviculture at Dr. Y.S. Parmar University of Horiculture and Forestry, Solan, Himachal Pradesh, India.

\section{Acknowledgements}

Authors are grateful to Forest Division Solan, Himachal Pradesh for providing necessary help and guidance.

\section{Author details}

'Department of Forestry, College of Agriculture, Fisheries and Forestry, Fiji National University, NasinuP.O. Box 7222, Fiji Islands. ${ }^{2}$ Department of Silviculture and Agroforestry, Dr. Y.S. Parmar University of Horiculture and Forestry, Solan, Himachal Pradesh, India.

Received: 23 June 2015 Accepted: 24 September 2015

Published online: 29 September 2015

\section{References}

Achard F, Beuchle R, Mayaux P, Stibig HJ, Bodart C, Brink A, Carboni S, Desclee B, Donnay F, Eva HD, Lupi A, Rasi R, Seliger R, Simonetti D (2014) Determination of tropical deforestation rates and related carbon losses from 1990 to 2010. Glob Chang Biol 20(8):2540-2554

Adams R, Adams D, Callaway J, Chang C, McCarl B (1993) Sequestering carbon on agricultural land: social costs and impacts on timber markets. Contemp Pol Issues 11:76-87

Ahluwalia MS (1998) Social, Cultural, and Economic History of Himachal Pradesh. Indus Publishing, New Delhi

Apan AA (1999) GIS applications in tropical forestry. Faculty of engineering and surveying. University of Southern Queensland, Toowoomba, Queensland, Australia

Baland JM, Bardhan P, Das S, Mookherjee D (2008) Forests to the People: Decentralization and Forest Degradation in the Indian Himalayas. World Dev 38(11):1642-1656

Bankoti TNS, Melkania U, Saxena AK (1986) Vegetation analysis along an altitudinal gradient in Kumaun Himalaya. Indian J Ecol 13:211-221

Bhandari BS, Mehta JP, Nautiyal BP, Tiwari SC (1997) Structure of Chir Pine (Pinus roxburghii Sarg.) community along an altitudinal gradient in Garhwal Himalaya. Int J Ecol Environ Sci 23:67-74.

Bolland LP, Ellis EA, Gholz HL (2007) Land use dynamics and landscape history in La Montana, Campeche, Mexico. Landsc Urban Plan 82:198-207

Champion HG, Seth SK (1968) A revised survey of the forest types of India. Government of India Publications Division, New Delhi

Chand K, Chatranta M (2014) GIS \& remote sensing technique to examine Landuse / Landcover Changes: A Case Study of emerging industrial hub of District Solan, Himachal Pradesh. Indian J Appl Res 4(6):218-220

Chase TN, Pielke RA, Kittel TGF, Nemani RR, Running SW (1999) Simulated impacts of historical land cover changes on global climate in northern winter. Clim Dyn 16:93-105

Chavez PS (1988) An improved dark object subtraction technique for atmospheric correction of multispectral data. Remote Sens Environ 24:459-479

Chowdhry P (2008) Gender Discrimination in Land Ownership. SAGE Publications, India

Congalton RG, Green K (1999) Assessing the Accuracy of Remotely Sensed Data: Principles and Practices. Lewis Publications, Boca Raton, USA

Department of Forest Farming and Conservation (1994) Annual Administrative Report. Himachal Pradesh

Deshingkar P, Bradley PN, Chadwick MJ, Leach G (1997) Adapting to climate change in a forest-based land use system: a case study of Himachal Pradesh, India. Stockholm Environment Institute, Stockholm

Fan F, Weng Q, Wang Y (2007) Land use and land cover change in Guangzhou, China, from 1998 to 2003, based on Landsat TM/ETM+ imagery. Sensors 7:1323-1342

Giri C, Defourny P, Shrestha S (2003) Land cover characterization and mapping of continental Southeast Asia using multi-resolution satellite sensor data. Int J Remote Sensing 24(21):4181-4196

Goldsmith FB (1998) Tropical rain forest. Chapman and hall, London 
Gouri MS, Morrison E, Mayers J (2004) Policy influences on forest-based livelihoods in Himachal Pradesh, India. International Institute for Environment and Development, London

Gupta HK (2007) Deforestation and Forest Cover Changes in the Himachal Himalaya, India. Int J Ecol Environ Sci 33(2-3):207-218

Haynes R, Alig R, Moore E (1994) Alternative Simulations of Forestry Scenarios Involving Carbon Sequestration Options. USDA Forest Service Gen. Tech. Rep. PNW-GTR-335, Pacific Northwest Research Station, Portland, Oregon.

International Panel on Climate Change (IPCC) (2001) Climate Change: The Scientific Basis. Contribution of Working Group I to the Third Assessment Report of the Intergovernmental Panel on Climate Change. Cambridge University Press, Cambridge, UK

Jensen JR (2007) Introductory Digital Image Processing: a remote sensing perspective. Science Press and Pearson Education Asia Ltd, Beijing

Joshi NR, Tiwari A (2011) Regeneration status and phytosociology in Quercus leucotrichophora (A. Camus) and Pinus roxburghii (Sarg.) mixed forests in two different aspects influenced by forest fires in community managed forests of Kumaun Central Himalaya, India. Nature and Science 9(9):160-166

Kennedy D, Hanson B (2006) Ice and history. Science 311:1673

Kumar S, Prashar D (2012) An analysis on changing trends of foodgrains in Himachal Pradesh. Int J Pharm Life Sci 3(6):1739-1742

Mclver DK, Friedl MA (2002) Using prior probabilities in decision-tree classification of remotely sensed data. Remote Sens Environ 81:253-261

Melkania NP, Melkania U (1987) Man and environment in Himachal Pradesh, India. In: Chadha SK (ed) Himachal Himalayas: ecology and environment. Today and Tomorrow's Printers and Publishers, New Delhi, pp 81-99

Ojima DS, Kalvin KA, Turner BL (1994) The global impact of land use change. BioScience 44(5):291-356

Overseas Development Administration Report (1993) Himachal Pradesh Forestry Project. Forestry Development in India and the Project Area. British High Commission, New Delhi

Pareta K (2014) Land Use and Land Cover Changes Detection using Multi Temporal Satellite Data. Int J Manag Soc Sci Res 3(7):10-17

Pareta K, Pareta U (2014) Climate Change Impact on Land and Natural Resource in Chamba Tehsil of Himachal Pradesh State, India. Int J Sc Tech 2(4):38-48

Planning Commission, Government of India (2005) Himachal Pradesh Development Report. State Plan Division, Academic Foundation

Ramachandra TV, Kumar U, Joshi NV (2012) Landscape Dynamics in Western Himalaya - Mandhala Watershed, Himachal Pradesh, India. A J G 12(1):1-8

Rogan J, Franklin J, Roberts DA (2002) A comparison of methods for monitoring multitemporal vegetation change using Thematic Mapper imagery. Remote Sens Environ 80(1):143-156

Sala OE, Chapin FS, Armesto JJ, Berlow E, Bloomfield J, Dirzo R, Huber-Sanwald E, Huenneke LF, Jackson RB, Kinzig A, Leemans R, Lodge DM, Mooney HA, Oesterheld M, Poff NL, Sykes MT, Walker BH, Walker M, Wall DH (2000) Biodiversity: global biodiversity scenarios for the year 2100. Science 287:1770-1774

Saxena AK, Pandey U, Singh JS (1978). On the ecology of oak forest in Nainital Hills, Kumoun Himalaya. In: Singh JS, Gopal B (eds) Glimpses of Ecology: Prof. R. Misra Commemoration Volume. Jaipur International Scientific Publication, Jaipur, India, pp 167-180

Saxena AK, Singh SP, Singh JS (1984) Population structure of forests of Kumaun Himalaya. Implications for management. J Environ Manage 19:307-324

Sharma H (2011) Crop Diversification in Himachal Pradesh: Patterns, Determinants and Challenges. Ind Jn of Agri Econ 66(1):97-114

Sharma DP, Bren L (2005) Effect of seasonal spectral variations on land cover classification. J Indian Soc Remote 33(2):203-209

Sharma RK, Sankhayan PL, Hofstad O, Singh R (2007) Land use changes in the Western Himalayan region - a study at watershed level in the state of Himachal Pradesh, India. Int J Ecol Environ Sci 33:197-206

Sharma RK, Sankhayan PL, Singh R (2010) Land Use Changes and Forest Degradation in a Himalayan Watershed: Analysis and Policy Alternatives. J Nat Res Pol Res 2(3):263-280

Sharma R, Rishi MS, Ahluwalia AS, Lata R (2014) Comparative change in landuse/ landcover in the buffer zone of Kashlog limestone mines, Darlaghat, Himachal Pradesh, India using remote sensing and GIS tools. Int J Remote Sens Geosci 3(6):27-30

Singh RB (1992) Dynamics of Mountain Geosystems. Ashish Pub, New Delhi

Singh RB (1999) Land use change, diversification of agriculture and agroforestry in North-west India. In: Haque T (ed) Land Use Planning in India. NCAEPR, New Delhi, pp 122-130
Singh DV, Sikka BK (1992) Wood balance study of Himachal Pradesh. Himachal Pradesh University, Shimla, Agro Economic Research Centre

Singh JS, Singh SP (1984) An integrated Ecological study of Eastern Himalaya with Emphasis on Natural Resources. Kumaun University, Nainital

Singh JS, Rawat YS, Chaturvedi OP (1984) Replacement of oak forest with pine in the Himalaya affects the nitrogen cycle. Nature 311:54-56

Singh SK, Chandel V, Kumar H, Gupta H (2014) RS \& GIS based urban land use change and site suitability analysis for future urban expansion of Parwanoo planning area, Solan, Himachal Pradesh (India). Intl J Dev Res 4(8):1491-1503

Sohl TL, Sohl LB (2012) Land-Use Change in the Atlantic Coastal Pine Barrens Ecoregion. Geogr Rev 102(2):180-201

Sohl TL, Gallant AL, Loveland TR (2004) The Characteristics and Interpretability of Land Surface Change and Implications for Project Design. Photogramm Eng Rem S 70(4):439-448

Stokes V (1983) Need for Substitute Packaging for Environmental Harmony. In: National Workshop on substituting forest timber for packaging of horticultural produce, tea, tobacco and textiles, Vigyan Bhawan, New Delhi, 30-31 July 1983.

Tiwari JC, Singh SP (1982) Vegetation analysis of a forest lying in transition zone between lower and upper Himalayan moist temperate forest. In: Paliwal GS (ed) The Vegetational Wealth of Himalayas. Puja Publishers, New Delhi, pp 104-119

Tolba MK, El-Kholy OA (1992) The World Environment 1972-1992: Two Decades of Challenge. Chapman \& Hall, London

Vasan S (1998) Political Ecology of Timber Rights in the Western Himalayas. In: Proceedings of the IGES International Workshop on Forest Conservation Strategies for the Asia and Pacific Region, Institute for Global Environmental Strategies, Kanagawa, Japan, 21-23 July, 1998

Vitousek PM, Mooney HA, Lubchenco J, Melillo JM (1997) Human domination of earth's ecosystems. Science 277:494-499

Wu W, Shao G (2002) Optimal. Combinations of Data, Classifiers, and sampling methods for Accurate Characterizations of deforestation" Can J Remote Sens 28(4):601-609

Yang X (2001) Change Detection Based on Remote Sensing Information Model and its Application on Coastal Line of Yellow River Delta. Earth Observation Research Center, Tokyo, China

\section{Submit your manuscript to a SpringerOpen ${ }^{\odot}$ journal and benefit from:}

- Convenient online submission

- Rigorous peer review

- Immediate publication on acceptance

- Open access: articles freely available online

- High visibility within the field

- Retaining the copyright to your article

Submit your next manuscript at $>$ springeropen.com 